Nataliia Yuhan,

Doctor of Philology, associate professor, Preparatory Department for Training of Foreigners, Taras Shevchenko National University of Kyiv, 90, Vasylkovska Str., Kyiv, Ukraine

\title{
MULTIMEDIA TECHNOLOGIES OF TEACHING "RUSSIAN LANGUAGE" TO FOREIGN STUDENTS AT THE INITIAL STAGE
}

In the $21^{\text {st }}$ century, The National Doctrine of Education Development in Ukraine determines the following priority ways of education modernization: forming high level of every society member's information culture, implementing innovative teaching methods using computer technologies into the educational process. The question is about deepening education content, improving pedagogical methods of information and knowledge operating, using multimedia technologies at lessons. At the Preparatory Department for Training of Foreigners at Taras Shevchenko National University of Kyiv, "Russian language" is taught to foreign students basing on the multimedia course "Time to speak Russian". The research is aimed at assessing the effectiveness of the implementation of this multimedia complex into practical classes. The article presents the results of a comparative analysis of teaching the Russian language to small groups of foreign students (up to 10 students), in 4 groups (40 students) at the initial stage using multimedia technologies and traditional teaching methods (explanation of new material, consolidation of knowledge, generalization of knowledge, improvement of skills, assessment of knowledge, development of speech). The type of multimedia technologies use at different kinds of the Russian language practical classes has significant differences. With almost the same level of the acquired knowledge, multimedia technologies facilitate the absorption of new vocabulary and grammatical rules, qualitative consolidation of new knowledge, improvement of skills. Also they stimulate cognitive interest, intellectual and creative potential, strengthen foreign students' motivation to learn the Russian language. In general, multimedia technologies use makes it possible to increase the effectiveness of teaching.

Keywords: multimedia technologies, foreign students, speech practice, cognitive interest, thinking activation, creativity, teaching efficiency.

\section{Introduction}

The informatization of education in Ukraine as a component of general informatization of the modern life should solve the task of preparing a new generation for its productive activities in the information society. The implementation of modern computer-oriented and telecommunication technologies into the educational process of higher educational institutions opens up new opportunities for modernizing methods of teaching academic disciplines, developing creative, communicative, personcentered approaches, increasing the efficiency, mobility and competitiveness of the national education system.

The issue of using information technologies for teaching foreign students from Europe, America, China, Morocco, the United Arab Emirates, etc. at Ukrainian universities is of particular importance nowadays. The education system in these countries is focused on computers and Internet resources use. The absence of lessons with the application of information technologies is often perceived by foreign students as conservatism and even the national education system backwardness, which does not make positive impression about the country and also stimulates students to search for the additional learning material. This is the reason for the research topic relevance.

The emergence of new teaching tools based on computer technologies has made the modern educational pro- cess more diverse and multidimensional. Up to date, multimedia technologies are the most promising and popular teaching information means that help to create entire images collections, texts and data that are accompanied by sound, video, animation and other visual effects $[4, \mathrm{p}$. 11].

Among modern methods of teaching Russian as a foreign language (RFL), multimedia technologies play a significant role. The scientific literature review on the issue has shown that in the higher education theory and practice there is great experience of creating and using computer technologies for teaching Russian to foreign students. First of all, this applies to the modern Englishlanguage complexes for studying RFL, which are accompanied by CD ROMs / DVDs with original author's audio recordings and multimedia programs for use in classrooms and in students' independent work on the academic discipline [10-14]. The issues of creating and implementing information technologies into the teaching Russian as foreign are actively being developed in the Post-Soviet space (by Zh. Azimbaeva, A. Atabekova, A. Bohomolov, S. Zhelezniakova, Zh. Zherebtsova, T. Izotova, N. Martirosian, E. Mileiko, E. Nikolenko, O. Rudenko-Morhun, L. Dunaieva, A. Arkhanhelska, E. Litvinova, I. Vialykh, E. Bobrova, S. Rukavishnikova, A. Triapelnikov, L. Chumak, I. Chukhlebova, et. al.). The scientists seek to understand the issue of computer technology use in the 
methodological or linguo-culturological aspects [3; 7], classify modern technologies and to describe them [2;9], provide recommendations for creating various audio and visual means and multimedia educational complexes for teaching Russian $[1 ; 6 ; 8]$.

At the same time, it should be noted that scientific works on the issue of multimedia programs use have a predominantly descriptive character. The effectiveness of some multimedia projects popular in the Internet which are actively used by RFL teachers has not yet become a scientific research subject yet.

At the Preparatory Department for Training of Foreigners (Taras Shevchenko National University of Kyiv), "Russian language" is taught to foreign students by means of the multimedia course "Time to speak in Russian".

The paper aims to study the effectiveness of using this multimedia complex at different stages of the learning material presentation and foreign students' knowledge assessment.

\section{Research methods}

We have been using the multimedia program "Time to speak Russian" to teach Russian to foreign students during 3 years (2014-2017) (developed by A. Petanov, Yu. Kovalenko, the project supervisor: V. L. Stepanenko, A. N. Bogomolov, M. M. Nakhabina, programmers: A. Belozerov, S. Bezrukov) [5]. 10 basic multimedia project topics were included in the training course (10 hours were allocated to each topic, in total - 100 hours). The classes were held at the end of the $1^{\text {st }}$ semester and at the beginning of the $2^{\text {nd }}$ semester (approximately on the $13^{\text {th }}-26^{\text {th }}$ week). The Russian-English program version was chosen for the lessons but students from China, Mexico and Morocco used the Russian-Chinese, RussianSpanish and Russian-French multimedia project versions. Thus, foreign students receive the entire methodological commentary (translation of words and expressions, formulation of tasks, grammatical commentary, regional information, etc.) while working on the course in Russian, English and their native language. Such an approach makes it possible to create a linguistic situation that is most comfortable for foreigners at the lesson, and, consequently, helps overcome the psychological barrier which is peculiar for the initial stage of studying any foreign language.

The basic course "Time to speak Russian" consists of the lessons on a modular basis. This is the main program part. Its "core" is a multi-series animated film, whose characters are made of plasticine. This form emphasizes the conventionality of what is happening and, at the same time, imitates reality in the game form.

We also used a section "Dictionary" including the necessary lexical minimum, "Testing" including summary control tasks blocks, recommended for students to perform after finishing the work on a certain lexical and grammatical topic. The multimedia resource section "Grammar" contains the basic grammar necessary for communication in Russian at the initial level. The sections "Library" and "Media Library" not only expand students' vocabulary but help make the Russian language learning process more meaningful and entertaining: they include a variety of songs (folk and modern), excerpts from popular Russian films, language learning games, crossword puzzles and other interactive excesses. With the use of these sections foreigners can develop fluent speech, listening and comprehensive skills, and also in an entertaining way to revise the acquired vocabulary and learn new expressions and phrases.

In order to examine the program effectiveness we conducted an experiment during 3 years among 40 foreign students, united into 4 groups $(9,10,9,11$ students). They came to study in Ukraine from Morocco (17), China (14), Iran (2), South Korea (2), Mexico (1), Afghanistan (1). The experiment was conducted in the second semester, during 21 academic weeks. By this time (after $18^{\text {th }}$ week) all the students who took part in the experiment passed written and oral exams in the Russian language, and therefore had a sufficient knowledge level to perceive and assimilate the new learning material presented in the "Lesson 9" of the multimedia program.

Let us indicate the average academic achievement score in each group according to the first session results (basing on a 100-point scale): group $1-83$ points; group $2-80$ points; group $3-79$ points; group $4-81$ points.

Each group was divided into 2 subgroups. During one academic week, one subgroup studied the topic "Visiting someone" using multimedia technologies. The second one studied the same topic in a traditional way, without involving Internet resources, audio and video equipment (10 hours for subgroup). The following types of practical classes were conducted:

1) explanation of the new learning material;

2) knowledge consolidation;

3) generalization of knowledge, improvement of skills;

4) development of speech;

5) assessment of knowledge.

As part of the lesson "Visiting someone" the following lexical constructions were studied: «пойти в гости» (go to visit), «приехать к другу домой» (come to a friend's house), «памятник композитору» (a monument to a composer), «подарить подруге» (give to a friend), «без подарка» (without a present), «для него» (for him), «собираться вместе» (get together), «торт с розой и кремом» (a cake with a rose and cream), «сколько тебе лет?» (how old are you?), «ей 25 лет» (she is 25 years old).

The following grammatical topics were studied: “Movement verbs «пойти/поехать» 'go', прийти/приехать "come",, "Dative case in the meaning of action addressee", "The instrumental case of nouns and pronouns", "The reflexive verbs in Russian. Reflexive verbs conjugation", "Genitive case for expressing the absence of an object (preposition «без»/without', the subject purpose (preposition «для»/'for'). The development of speech took place during practical classes in the 
process of discussing linguistic and cultural studies topics "Come to visit", "National holidays".

After each lesson, the Russian Language students were interviewed and surveyed. The results obtained were summarized in the tables below and made it possible to draw conclusions about the effectiveness of using multimedia program "Time to speak Russian" for teaching
Russian as a foreign language during pre-university practice.

\section{Discussion}

First of all, we should note that the results of mastering the academic topic obtained in practical lesson No. 5 (type: knowledge assessment) in each of the two subgroups of foreign students have almost no differences: $\mathrm{p}>$ 0.05 (the difference is 0.1 points) (Table 1).

Comparative characteristics of knowledge level in the subgroup 1 using the multimedia

Table 1. program "Time to speak in Russian" and in the subgroup 2 using traditional methods

\begin{tabular}{|l|c|c|c|}
\hline \multicolumn{1}{|c|}{ level of knowledge } & $\begin{array}{c}\text { Subgroup 1 }(\mathrm{n}=20) \\
(\text { score })\end{array}$ & $\begin{array}{c}\text { Subgroup 2 } \\
(\mathrm{n}=20)(\text { score })\end{array}$ & $\mathrm{p}$ \\
\hline Testing results score $(\mathrm{M} \pm \mathrm{SD})$ & $4,4 \pm 0,78$ & $4,3 \pm 0,72$ & $\mathrm{p}>0,05$ \\
\hline
\end{tabular}

$p$ - the significance level of differences in the two subgroups.

The students of two subgroups after each of the five classes on the topic were offered a questionnaire, according to which they had to assess the lesson by the following criteria: comprehensibility, consistency, illustration, creativity, and then to assess a lesson. The mark for each section of the questionnaire was given according to a fivepoint system. The questionnaire results are represented in Table 2. The differences in the indices of two subgroups of foreign students are considered statistically significant (according to the Mann-Whitney U criterion).
As shown, according to all the stated criteria the marks of the classes conducted on the basis of the multimedia presentation are higher than the ones basing on traditional approaches and teaching methods. The highest marks were given by the students for the educational material presentation consistency and the creative approach in its selection and presentation at the lesson (4.85 and 4.8 , respectively). The greatest difference in the scores given by two subgroups of students was noticed according to the criteria "creative approach" ( 0.49 points $)$ and "illustrative character" ( 0.43 points $)$.

Table 2 .

The survey results in the subgroups 1 and 2

\begin{tabular}{|c|l|c|c|c|}
\hline \multirow{2}{*}{ № } & \multicolumn{1}{|c|}{ Questionnaire blocks } & \multicolumn{3}{|c|}{$\begin{array}{c}\text { Results } \\
\text { M } \pm \text { SD }\end{array}$} \\
\cline { 3 - 5 } & & $\begin{array}{c}\text { Subgroup №1 (n=20) } \\
\text { (score) }\end{array}$ & $\begin{array}{c}\text { Subgroup № 2 } \\
\text { (n=20) (score) }\end{array}$ & $\mathrm{p}$ \\
\hline 1. & Availability & $4,74 \pm 0,25$ & $4,43 \pm 0,4$ & $\mathrm{p}<0,001$ \\
\hline 2. & Consistency & $4,85 \pm 0,25$ & $4,58 \pm 0,64$ & $\mathrm{p}<0,001$ \\
\hline 3. & Illustrative character & $4,76 \pm 066$ & $4,33 \pm 0,8$ & $\mathrm{p}<0,001$ \\
\hline 4. & Creativity & $4,80 \pm 0,41$ & $4,31 \pm 0,68$ & $\mathrm{p}<0,001$ \\
\hline 5. & General score & $4,57 \pm 0,48$ & $4,21 \pm 0,73$ & $\mathrm{p}<0,29$ \\
\hline
\end{tabular}

$p$ - the significance level of differences in the two subgroups.

In Table 3, we have summarized the questionnaire results according to the level of the students' teaching material perception. All the respondents were divided into 3 groups: high, medium and low perception levels. The additional criteria were introduced to study the multimedia program effectiveness in the RLF teaching: "cognitive interest activation" and "thinking processes activation". The "cognitive interest activation" indicator shows the students' interest degree in the material studied at the lesson presented in a multimedia presentation form and conducted using traditional teaching forms and methods. The students assessed the lesson content, the comprehensibility for foreigners, the material design specifics and its presentation, the material structuring facilitating better memorization of new words, rules and exceptions. While assessing classes according to the "thinking processes activation" criterion the students had to pay attention to the examples and illustrations abundance and diversity, the creativity of the approaches and methods used in the multimedia program and during traditional practical classes.

Similar to the Table 2, in this table there are more students who highly assessed practical classes using the Internet program as compared to the number of the students who have put high scores for lessons where Russian was taught according to the traditional methods. The foreign students consider computer lessons to be comprehensible and illustrative; they have a creative approach to the educational material presentation. It is worth noting that according to the criterion "illustrative character" multimedia lessons were very well perceived by the re- 
spondents $(100 \%)$. Such classes are characterized by the comprehensibility (90\%), and a creative approach for their development (90\%). The comparison of the indices of the two subgroups of the students with a low level of educational material perception has shown that only 1 student (according to the criterion "logic nature") has not perceived the multimedia presentation teaching material, and 16 respondents have not perceived the lessons with the traditional approach ( 2 persons according to the criterion "comprehensibility", 3 persons according to the crite- rion "logic nature", 7 respondents according to the criterion "illustrative character", 4 students according to the criterion "creative approach"). The reduction of the low level of material perception in the multimedia version of the lessons is very important in terms of teaching Russian as a foreign language. The multimedia technologies use facilitates the teaching effectiveness in low-performing groups of foreign students.

The survey results according to the level of the students'

Table 3.

\section{learning material perception in Subgroup 1 and 2}

\begin{tabular}{|c|c|c|c|c|c|}
\hline № & \multicolumn{2}{|c|}{ Questionnaire blocks } & \multicolumn{3}{|c|}{$\begin{array}{l}\text { Educational material perception Level (depending } \\
\text { on the students' number (\%)) }\end{array}$} \\
\hline \multicolumn{3}{|c|}{ cognitive interests activation } & high & medium & low \\
\hline \multirow[t]{2}{*}{1.} & \multirow[t]{2}{*}{ Comprehensibility } & Subgroup 1 & $18(90 \%)$ & $2(10 \%)$ & - \\
\hline & & Subgroup 2 & $9(45 \%)$ & $9(45 \%)$ & $2(10 \%)$ \\
\hline \multirow[t]{2}{*}{2.} & \multirow[t]{2}{*}{ Consistency } & Subgroup 1 & $15(75 \%)$ & $4(20 \%)$ & $1(5 \%)$ \\
\hline & & Subgroup 2 & $8(40 \%)$ & $9(45 \%)$ & $3(15 \%)$ \\
\hline \multicolumn{6}{|c|}{ thinking processes activating } \\
\hline \multirow[t]{2}{*}{3.} & \multirow[t]{2}{*}{ Illustrative character } & Subgroup 1 & $20(100 \%)$ & - & - \\
\hline & & Subgroup 2 & $5(25 \%)$ & $8(40 \%)$ & $7(35 \%)$ \\
\hline \multirow[t]{2}{*}{4.} & \multirow[t]{2}{*}{ Creativity } & Subgroup 1 & $18(90 \%)$ & $2(10 \%)$ & - \\
\hline & & Subgroup 2 & $6(30 \%)$ & $10(50 \%)$ & $4(20 \%)$ \\
\hline
\end{tabular}

At the same time in order to assess the effectiveness of the multimedia program "Time to speak Russian" we used interviewing method together with questioning. It should be noted that not all foreign students due to their mentality, individual character traits, insufficient level of Russian and English communication skills wanted and could express their thoughts about the conducted practical classes. After each session, they were asked to what extent, in their opinion, the use or non-use of the multimedia program at this type of practical lessons is relevant and effective, increases interest in the discipline, and promotes their personal growth.

The interviewing has resulted in the students' conclusion that the kind of multimedia technologies use at different types of practical classes in the Russian language has significant differences.

The multimedia program "Time to speak Russian" has a significant potential. The program can be used during a lesson when explaining a new topic to students (visibility, charts and exercises when learning new words, expressions and grammatical rules); in the process of knowledge consolidation (animated videos, texts for listening and comprehension skills development, lexical and grammatical exercises); also in the process of generalizing knowledge and improving skills (use of additional animated films, songs, listening tasks, language learning games, crossword puzzles); when assessing students' knowledge and skills (computer testing); when develop- ing and improving speaking skills (texts and videos on colloquial topics, interactive tasks analysis). The students paid special attention to the computer testing material, which included both traditional tasks for assessing knowledge and assignments using audio texts, videos, pictures, etc.

\section{Conclusions}

The implementation of the innovative pedagogical technologies in the process of teaching Russian as a foreign language at universities preparatory departments at the current stage of Ukrainian education system development is relevant and promising. Such technologies provide conditions for the students' professional and personal development.

Assessing the results of using the multimedia program "Time to speak Russian" for teaching Russian as a foreign language to the foreign students we can state that the multimedia technologies facilitate the rapid acquisition of new lexical units and grammar rules, improves speaking skills, stimulates cognitive interest, intellectual and creative potential, strengthens the foreign students' motivation to study the Russian language. In general, the multimedia technologies use makes it possible to improve the process of teaching Russian as a foreign language.

The further research studies in this field are planned to cover the issue of applying video technologies (animation, videos, films, etc.) in the process of teaching Russian to foreign students. 


\section{REFERENCES}

1. Azimbaeva, Zh. (2009). Primenenie elektronnykh uchebno-metodicheskikh posobii $\mathrm{v}$ protsesse obucheniia russkomu iazyku kak inostrannomu [The use of electronic teaching aids in the process of teaching Russian as a foreign language]. Vestnik Karagandinskogo gosudarstvennogo universiteta - Bulletin of Karaganda State University, 4, 145-156 [in Russian].

2. Atabekova, A. A. (2008). Novye kompiuternye tekhnologii v prepodavanii russkogo yazyka kak inostrannogo [New computer technologies in teaching Russian as a foreign language]. Moscow: RUDN [in Russian].

3. Bogomolov, A. N. (2008). Virtualnaya yazykovaya sreda obucheniya russkomu yazyku kak inostrannomu (ligvokulturologicheskiy aspekt) [Virtual language environment for teaching Russian as a foreign language (linguoculturological aspect)]. Moscow: MAKS Press [in Russian].

4. Buzduhan, O. A. (2015). Vykorystannia multymediinykh zasobiv navchannia $\mathrm{v}$ konteksti osuchasnennia procesu vykladannia inozemnoi movy [The use of multimedia teaching in the context of the modernization of teaching foreign languages]. Nauka i osvita - Science and Education, 2, 10-15 [in Ukrainian].

5. Vremya govorit po-russki: multimediinyi kurs [Time to speak Russian: multimedia course]. (n. d.). Retrieved from: http//speakrussian.cie.ru/time_new/rus/course.html [in Russian].

6. Rukavishnikova, S. M. (2011) Ispolzovanie informatsionnykh tekhnologiy pri obuchenii fonetike na nachalnom etape [The use of information technologies for teaching phonetics at the initial stage]. Tekhnologii obucheniia RKI (iazykam) $i$ diagnostika rechevogo razvitiya - Technologies for teaching RCTs (languages) and diagnostics of speech development: materials of the XVII International Scientific and Practical Conference

\section{ЛИТЕРАТУРА}

1. Азимбаева Ж. А. Применение электронных учебно-методических пособий в процессе обучения русскому языку как иностранному / Ж. А. Азимбаева // Вестник Карагандинского государственного университета. - 2009. - № 4. - С. 145-156.

2. Атабекова А. А. Новые компьютерные технологии в преподавании русского языка как иностранного / А. А. Атабекова. - М. : РУДН, 2008. - 245 с.

3. Богомолов А. Н. Виртуальная языковая среда обучения русскому языку как иностранному (лигвокультурологический аспект) / А. Н. Богомолов. - М. : МАКС Пресс, 2008. - 320 c.

4. Буздуган О. А. Використання мультимедійних засобів навчання в контексті осучаснення процесу викладання іноземної мови / О. А. Буздуган // Наука і освіта. - 2015. - № 2. - С. 10-15. under the auspices of MAPRYAL, Minsk, 2 - February 3, 2011. (pp. 303-304). Minsk: BGEU [in Russian].

7.Triapelnikov, A. V. (2014). Integratsiya informatsionnykh i pedagogicheskikh tekhnologiy $v$ obuchenii RKI (metodologicheskiy aspekt) [Integration of information and pedagogical technologies in the teaching of RCTs (methodological aspect)]. Moscow [in Russian].

8. Chukhlebova, I. A. (2016). Intensifikatsiya obucheniia RKI $\mathrm{s}$ ispolzovaniem informatsionnykh $\mathrm{i}$ kommunikativnykh tekhnologiy [Integration of information and pedagogical technologies in the teaching of RLI (methodological aspect)]. Vestnik nauchnykh konferentsiy - Bulletin of scientific conferences, 9-2 (13), 116118 [in Russian].

9. Iakovlev, S. M. (2016). Ispolzovanie kompiuternykh tekhnologiy pri obuchenii russkomu yazyku kak inostrannomu [Use of computer technology in teaching Russian as a foreign language]. Nauka - obrazovaniyu, proizvodstvu, ekonomike - Science for education, production, economics: Proceedings of the $68^{\text {th }}$ Regional scientific and practical conference of teachers, researchers and graduate students, 11-12, 82-83. Vitebsk: VGU Masherova [in Russian].

10.Berdichevsky, A. (2007). Steps. Haaga-Helia University of Applied Sciences [in English].

11. Gillespie, D., \& Wade, T. (2010). Russian grammar. Third edition. Wiley-Blackwell [in English].

12. Kharav, S., \& Dunn, J. (2009). Russian grammar. A practical. Guide. Routledge [in English].

13. Kharav, S., \& Dunn, J. (2010). Russian grammar. A practical. Workbook. Routledge [in English].

14. Wade T., \& Gillespie, D. (2012). Russian grammar. Workbook. Second edition. Wiley-Blackwell [in English].

5. Время говорить по-русски : мультимедийный курс [Электронный pecypc] // http//speakrussian.cie.ru/time_new/rus/course.htm.

6. Рукавишникова С. М. Использование информационных технологий при обучении фонетике на начальном этапе / С. М. Рукавишникова // Технологии обучения РКИ (языкам) и диагностика речевого развития : материалы XVII Международной научнопрактической конференции под эгидой МАПРЯЛ, Минск, 2 - 3 февраля 2011 г. - Мн. : БГЭУ, 2011. - С. 303-304.

7. Тряпельников А. В. Интеграция информационных и педагогических технологий в обучении РКИ (методологический аспект) / А. В. Тряпельников. М., 2014. -80 c. 
8. Чухлебова И. А. Интенсификация обучения РКИ с использованием информационных и коммуникативных технологий / И. А. Чухлебова // Вестник научных конференций. - Тамбов : ООО «Консалтинговая компания Юком», 2016. - № 9 - 2 (13). - С. 116118.

9. Яковлев С. М. Использование компьютерных технологий при обучении русскому языку как иностранному / С. М. Яковлев. - Наука - образованию, производству, экономике: материалы XXI (68) Региональной научно-практической конференции преподавателей, научных сотрудников и аспирантов, Витебск, 11 - 12 февраля 2016 г. - Витебск : ВГУ имени П. М. Машерова, 2016. - С. 82-83.
10. Berdichevsky A. Steps / A. Berdichevsky. Haaga-Helia University of Applied Sciences, 2007. - 130 p.

11. Gillespie D. Russian grammar. Third edition / David Gillespie, Terence Wade. - Wiley-Blackwell, 2010. - $298 \mathrm{p}$.

12. Kharav S. Russian grammar. A practical. Guide / Shamil Kharav, John Dunn. - Routledge, 2009. - 468 p.

13. Kharav S. Russian grammar. A practical. Workbook / Shamil Kharav, John Dunn. - Routledge, 2010. $232 \mathrm{p}$.

14. Wade T. Russian grammar. Workbook. Second edition / Terence Wade, David Gillespie. - WileyBlackwell, 2012. - 253 p.

\section{Наталія Леонідівна Юган, доктор філологічних наук, доиент Підготовчого відділення для навчання іноземних громадян, Киівський начіональний університет імені Тараса Шевченка, вул. Васильківська, 90, м Київ, Україна}

\section{МУЛЬТИМЕДІЙНІ ТЕХНОЛОГІЇ ВИКЛАДАННЯ ДИСЦИПЛІНИ «РОСІЙСКА МОВА» СТУДЕНТАМ-ІНОЗЕМЦЯМ ПОЧАТКОВОГО ЕТАПУ НАВЧАННЯ}

Національна доктрина розвитку освіти України в XXI столітті пріоритетними шляхами модернізації системи освіти визначає формування високого рівня інформаційної культури кожного члена суспільства, впровадження інноваційних методів навчання з використанням комп'ютерних технологій в практику освітньо-виховного процесу. В першу чергу мова йде про поглиблення змісту освіти, вдосконалення педагогічних прийомів оперування інформацією та знанням, використання на заняттях мультимедійних технологій. На Підготовчому відділенні для навчання іноземних громадян Київського національного університету імені Тараса Шевченка викладання дисципліни «Російська мова» студентам-іноземцям проводиться з використанням мультимедійного курсу «Час говорити російською». Метою нашої роботи є вивчення ефективності впровадження мультимедійного комплексу на практичних заняттях. У статті представлено порівняльний аналіз результатів навчання у малих групах (до 10 осіб) студентів-іноземців (усього 4 групи, 40 студентів) російській мові на початковому етапі 3 використанням мультимедійних технологій та з традиційним підходом на різних етапах процесу засвоєння навчального матеріалу (пояснення нового матеріалу; закріплення знань; узагальнення знань, вдосконалення умінь й навичок; контроль; розвиток мовлення). Ми дійшли висновку, що характер використання мультимедійних технологій на різних типах практичних занять з російської мови має значні відмінності. При практично однаковому рівні отриманих знань упровадження мультимедійних технологій сприяє швидкому засвоєнню нової лексики та граматичних правил, якісному закріпленню нових знань, вдосконаленню умінь й навичок, широкій мовній практиці, ефективній та нестандартній перевірці знань, а також стимулює пізнавальний інтерес, інтелектуальний та творчий потенціал, посилює мотивацію студентів-іноземців до вивчення російської мови. В цілому використання мультимедійних технологій дозволяє підвищити ефективність навчання.

Ключові слова: мультимедійні технології, студенти-іноземці, мовна практика, пізнавальний інтерес, активізація мислення, творчий потенціал, ефективність навчання.

Submitted on April, 10, 2017 